\title{
Ectoparasites of the endemic rodent Abrocoma bennetti (Hystricomorpha: Abrocomidae) from semiarid Chile
}

\section{Ectoparásitos del roedor endémico Abrocoma bennetti (Hystricomorpha: Abrocomidae) en Chile semiárido}

\author{
Andrea Yáñez-Meza ${ }^{1}$, Lucila Moreno ${ }^{2 *} \&$ Carezza Botto-Mahan ${ }^{1}$ \\ ${ }^{1}$ Departamento de Ciencias Ecológicas, Facultad de Ciencias, Universidad de Chile, Las Palmeras 3452, Ñuñoa, Santiago, \\ Chile. \\ ${ }^{2}$ Departamento de Zoología, Facultad de Ciencias Naturales y Oceanográficas, Universidad de Concepción, Casilla 160-C, \\ Concepción, Chile. \\ *E-mail: lumoreno@udec.cl
}

\begin{abstract}
A total of 13 individuals of the rodent Abrocoma bennetti were captured and 354 ectoparasites belonging to 10 different species were collected and analyzed. The most abundant species was the Phthiraptera Monogyropus longus (61.54\%), followed by the Siphonaptera Neotyphloceras chilensis (38.46\%). In this study Gyropus distinctus (15.38\%) is reported as new record for $A$. bennetti, previously described for Octodon degus, a rodent usually living in sympatry with $A$. bennetti. For the first time the flea Delostichus smiti, and the mites Ornithonyssus sp. and Androlaelaps fahrenholzi are recorded in this rodent species.
\end{abstract}

\section{RESUMEN}

Se capturó un total de 13 individuos del roedor Abrocoma bennetti y 354 ectoparásitos de 10 especies diferentes fueron recolectados y analizados. La especie más abundante fue el phthiraptero Monogyropus longus (61,54\%), seguido por el sifonáptero Neotyphloceras chilensis (38,46\%). En este estudio Gyropus distinctus $(15,38 \%)$ es reportado como nuevo registro para $A$. bennetti, descrito previamente en Octodon degus, un roedor que usualmente vive en simpatría con $A$. bennetti. Se registran por primera vez la pulga Delostichus smiti y los ácaros Ornithonyssus sp. y Androlaelaps farhenholzi en esta especie de roedor.

The Bennett's Chinchilla Rat or Abrocoma bennetti Waterhouse 1837 is a medium-sized endemic rodent, widely distributed in Chile, from Copiapó Valley $\left(27^{\circ} 18^{\prime} \mathrm{S}\right.$, $\left.70^{\circ} 29^{\prime} \mathrm{W}\right)$ to Biobío River (36 $\left.49^{\prime} \mathrm{S}, 73^{\circ} 10^{\prime} \mathrm{W}\right)$ and from sea level up to 2000 masl (Muñoz-Pedreros \& Gil 2009). Its parasitic fauna as well as other biological interactions are scarcely reported in the literature, probably due to its low abundance with high variability among years. Some few reports have documented the presence of five lice species: Monogyropus longus Ewing 1924, Phtheiropoios pearsoni Werneck 1948, Eulinognatus chilensis Gómez 1998, Abrocomophaga chilensis Emerson and Price 1976, Abrocomaphthirus hoplai Durden and Webb 1999 (Ewing 1924; Gómez 1998; Moreno et al. 2005); two ticks: Ixodes abrocomae Lahille 1916 and I. sigelos Keirans, Clifford and Corwin 1976 (González-Acuña et al. 2004), and eight fleas: Tetrapsyllus tantillus (Jordan \& Rothschild 1923), T. corfidii (Rothschild 1904), Delostichus coxalis (Rothschild 1909),
D. degus Beaucournu, Moreno and González-Acuña 2011, Ectinorus chilensis Lewis 1976, E. cocyti (Rothschild 1904), Neotyphloceras chilensis Jordan 1936 and Hectopsylla gemina Jordan 1939 (Beaucournu et al. 2014). There are not recorded mites. However, these evidences are fragmented in space and time, and they are entirely circumscribed to instantaneous recordings. In this study, we characterized the ectoparasitic fauna of $A$. bennetti, an endemic rodent, in a protected area for five consecutive summers.

This study was carried out in Las Chinchillas National Reserve (312'ㅇ $71^{\circ} 03^{\prime} \mathrm{W}$; Coquimbo Region), immersed in a semiarid-Mediterranean ecosystem with fluctuating temperatures between $15^{\circ}$ and $30^{\circ} \mathrm{C}$. Vegetation is mainly dominated by cactaceae on north face slopes, and shrubs on south face slopes, giving refuge to endemic small mammal species (Cortés et al. 1994). Abrocoma bennetti collection was carried out in five consecutive years (2009 - 2013) during the summer (January). To this end, specimens were collected 
using folding wire mesh live-animal-traps (trap dimension: $24 \mathrm{~cm} \times 8 \mathrm{~cm} \times 9 \mathrm{~cm}$; FORMA: Products and Services, Santiago, Chile) baited with rolled oats and equipped with cotton bedding. Traps were set on three locations within the reserve using two parallel linear transects (except in 2009 when only one location was sampled). Each transect consisted of 50 traps set $10 \mathrm{~m}$ apart, with the same distance between lines. Collection was carried out during five nights from 19:00 to 09:00 h. Captured rodents were weighed, measured, sexed and ear-tagged under short-term isoflurane anaesthesia. Their ectoparasites were collected by strongly brushing against hair above a white surface and placed them in individual vials with $70 \%$ alcohol. After recovering from anesthesia, specimens were released at the capture point. All manipulations were performed following the three Rs proposed by Goldberg (2010) and authorized by the Ethical Committee of Facultad de Ciencias (Universidad de Chile), the Chilean Agriculture and Livestock Bureau (SAG), and the Chilean National Forestry Corporation (CONAF).

In the laboratory, samples were prepared by conventional techniques and mounted on glass slides in Canada balsam for fleas and lice, and in Berlese for mites. Each sample was observed through classical microscopy and taxonomically determined following bibliographic material, keys and descriptions (Ewing 1924; Lewis 1976; Price \& Timm 2000; Castro \& Cicchino 2002; Krantz \& Walter 2009; Sánchez et al. 2012) and collections from Facultad de Ciencias Naturales y Oceanográficas, Universidad de Concepción, Concepción, Chile.

With this information prevalence was calculated $(\mathrm{P}$ : number of individuals of a host species infected with a particular parasite species/number of hosts examined $\times 100$ ), frequency (F: number of infected hosts), mean intensity (MI: total number of individuals from a particular parasite species in a sample of a host species/number of infected individual from host species in the sample), and mean abundance (MA: number of isolated parasite /total number of hosts analyzed) from ectoparasite species collected. The confidence intervals were calculated with bootstrap (5000 replicates). We used the free access software $\mathrm{R}$ project 3.0.2 (R Development Core Team 2009).

During the sampling period (2009 and 2013) a total of 13 individuals of $A$. bennetti were captured and processed. Overall, 354 ectoparasites were collected, mounted and identified, and they belonged to 10 species: three lice (Phthiraptera), five fleas (Siphonaptera) and two mites (Mesostigmata) (Table 1). No ticks were collected. Total prevalence was $84.6 \%$. The lice $M$. longus was the most prevalent and abundant ectoparasite $(\mathrm{P}=61.53 \%, \mathrm{MA}=$ 18.38), followed by the flea Neotyphloceras chilensis $(\mathrm{P}=$ $38.46 \%, \mathrm{MA}=1.15$ ).

Monogyropus longus and A. chilensis had been previously described in association with $A$. bennetti (Ewing 1924; Emerson \& Price 1976; Valim 2010). However, Gyropus distinctus Castro \& Cicchino 2002 had been recorded only for the rodents Octodon degus Molina 1782 and O. lunatus Osgood 1943 (Castro \& Cicchino 2002). Therefore, this finding in A. bennetti is a new record. This new association could be a secondary infestation from $O$. degus to $A$. bennetti, since they share similar habitats, but we cannot discard this could be a first step for a new parasite-host interaction or simply a rare interaction.

Regarding fleas, five species were reported (Table 1). All species reported in this study, except for D. smiti, had been previously reported in A. bennetti. Delostichus smiti had been isolated from $O$. degus and $A$. longipilis, rodents with which $A$. bennetti shares habitat. This flea has low specificity with respect to their hosts, and the presence in

TABLE 1. Ectoparasites collected from Abrocoma bennetti. N: total parasites; F: number of infected hosts, P: percentage of infected host, MI: mean intensity, MA: mean abundance, CI: confidence interval. / Ectoparásitos colectados desde Abrocoma bennetti. N: parásitos totales; F: numero de hospedadores infectados; P: porcentaje de hospedadores infectados; MI: intensidad media; MA: abundancia media; CI: intervalo de confianza.

\begin{tabular}{|c|c|c|c|c|c|}
\hline ECTOPARASITE & $\mathrm{N}$ & $\mathrm{F}$ & $\mathrm{P}$ & MI (CI) & $\mathrm{MA}(\mathrm{CI})$ \\
\hline \multicolumn{6}{|l|}{ Phthiraptera } \\
\hline Monogyropus longus & 239 & 8 & 61.54 & $29.87(13.25-47.12)$ & $18.34(5.9-32.76)$ \\
\hline Gyropus distinctus & 10 & 2 & 15.38 & $5(1-9)$ & $0.76(0-2.15)$ \\
\hline Abrocomophaga chilensis & 13 & 4 & 30.76 & $3.25(1.75-4.5)$ & $1(0.15-2.00)$ \\
\hline \multicolumn{6}{|l|}{ Siphonaptera } \\
\hline Neotyphloceras chilensis & 15 & 5 & $38.46(1.2-4.8)$ & $3(1.2-4.8)$ & $1.15(0.23-2.31)$ \\
\hline Delostichus smiti & 22 & 4 & 30.77 & $5.5(1.6-9.4)$ & $1.69(0.15-4.07)$ \\
\hline Tetrapsyllus corfidii & 15 & 3 & 23.08 & $5(1-7)$ & $1.15(0-2.77)$ \\
\hline Ectinorus chilensis & 10 & 3 & 23.08 & $3.33(1-8)$ & $0.5(0-2.08)$ \\
\hline Hectopsylla gemina & 2 & 1 & 7.69 & 2 & 0.15 \\
\hline \multicolumn{6}{|l|}{ Mesostigmata } \\
\hline Ornithonyssus sp. & 1 & 1 & 7.69 & 1 & 0.07 \\
\hline Androlaelaps fahrenholzi & 1 & 1 & 7.69 & 1 & 0.07 \\
\hline
\end{tabular}


A. bennetti could be a secondary infestation. Delostichus smiti would correspond to a new parasitic host association. The other species found had been recorded in some of the rodents living in sympatry with $A$. bennetti (e.g., O. degus, A. longipilis, A. olivaceus and $P$. darwini) (Beaucornu et al. 2014). Octodon degus is the rodent that shared the largest number of flea species (4 of the 5 found) with $A$. bennetti, which could be explained because these species share burrows, which would facilitate the parasite transmission between these two species (Fulk 1976).

Androlaelaps fahrenholzi Fonseca 1959 had been recorded on mammals of the orders Rodentia, Didelphimorphia, Microbiotheria, Xenarthra and Chiroptera (Till 1963; Tipton et al. 1966; Furman 1972; Lareschi \& Mauri 1998). In Chile, it has been reported in the marsupial Thylamys elegans from Las Chinchillas National Reserve (Plaza 2013) and the rodents Eligmodontia puerulus, Phyllotis xanthopygus and Phyllotis darwini (Silva de la Fuente 2014). Tylamys elegans and $P$. darwini live in sympatry with $A$. bennetti, and the finding of $A$. fahrenholzi reflects some degree of interaction between them. Whereas Ornithonyssus is a cosmopolitan mite associated with rodents such as Mus musculus, Rattus norvegicus and $R$. rattus (Baumstark et al. 2007). Likewise, the presence of Ornithonyssus and A. fahrenholzi mites represents a new record.

Abrocoma bennetti shares $50 \%$ of the parasite assemblage with $O$. degus, but only $20 \%$ with other sympatric species (Beaucornu et al. 2014). This result could be explained due to the phylogenetic closeness between $A$. bennetti and $O$. degus (Blanga-Kanfi et al. 2009). However, it should also be considered that these species can share burrows and nests, which favors parasite transfer (Fulk 1976).

The high ectoparasite prevalence detected in A. bennetti (84.6\%) could be explained by their gregarious behavior; therefore, ectoparasite exchange between hosts would be facilitated by direct contact. Abrocoma bennetti collection was carried out during the mating period of this species (Muñoz-Pedreros \& Gil 2009), an energetically demanding time, hence the high overall prevalence detected (mostly lice) may be explained, at least in part, by sampling bias. In fact, it has been described that immunocompromised animals and/or with low body condition would be more susceptible to infestation by ectoparasites, more specifically with lice, which complete their life cycle on the host, unlike fleas that are not tightly associated to host's condition. Therefore, it is necessary to conduct studies in other seasons to examine the assembly stability and to complete the taxonomic catalog of ectoparasites from small mammal species.

\section{ACKNOWLEDGEMENTS}

We thank C. Silva de la Fuente for her help with mite species and Dr. A. Cicchino for louse processing. FONDECYT
11090086, 1170367 and 11150875 provided funds for this study. AYM was supported by a CONICYT-Scholarship for Master's studies.

\section{REFERENCES}

Baumstark, J., Beck, W., Hofmann, H. 2007. Outbreak of tropical rat mite (Ornithonyssus bacoti) dermatitis in a home for disabled persons. Dermatology 215:66-68.

Beaucournu, J.C., Moreno, L., González-Acuña, D. 2014. Fleas (Insecta-Siphonaptera) of Chile: a review. Zootaxa 3900:151-203.

Blanga-Kanfi, S., Miranda, H., Penn, O., PunkPo, T., DeBry, R.W., Huchon, D. 2009. Rodent phylogeny revised: analysis of six nuclear genes from all major rodent clades. BMC Evolutionary Biology 9:71-83.

Castro, C., Cicchino, A. 2002. Las especies del género Gyropus Nitzsch, 1818 (Phthiraptera: Gyropidae) parasitas de Octodontidae (Mammalia: Rodentia). Revista Chilena de Historia Natural 75:293-298.

Cortés, A., Pino, C., Rosenmann, M. 1994. Balance hídrico del ensamble de micromamíferos de dos localidades de la región mediterránea árida del norte de Chile central: un estudio de campo. Revista Chilena de Historia Natural 67:65-77.

Emerson, K.C., Price, R.D. 1976. Abrocomophagidae (Mallophaga: Amblycera), a new family from Chile. The Florida Entomologist 59(4):425-428.

EwING, H.E. 1924. On the taxonomy, biology and distribution of the biting lice of the family Gyropidae. Proceedings U.S. National Museum 63(20):1-42.

FULK, G.W. 1976. Notes on the activity, reproduction, and social behavior Octodon degus. Journal of Mammology 57: 495505 .

Furman, D.P. 1972. Laelaps mites (Laelapidae: Laelapinae) of Venezuela. Brigham Young University Science BulletinBiological Series 17(3):1-58

GoldBerg, A.M. 2010. The principles of humane experimental technique: is it relevant today? ALTEX Journal 27(2):2527.

Gómez, M.S. 1998. Two Anoplura species from rodents in Chile: Hoplopleura andina Castro, 1981 (Hoplopleuridae) from Geoxus valdivianus (Cricetidae) and Eulinognathus chilensis n. sp. (Polyplacidae) from Abracoma bennetti (Abracomidae). Research and Reviews in Parasitology 58(1):49-54.

GonzÁlez-Acuña, D., Venzal, J.M., Guglielmone, A.A. 2004. Nuevos hospedadores y localidades de Ixodes sigelos e Ixodes auritulus (Acari: Ixodidae) en Chile. Gayana 68(1):108-111.

Johnson, P.T. 1957. A classification of the Siphonaptera of South America. Memoirs of the Entomological Society of Washington (No. 5). Published by Entomological Society of Washington, Washington, DC. 299 pp.

Krantz, G.W., Walter, D.E. 2009. A manual of acarology. Texas Tech University Press, Lubbock, Texas, USA. 807pp.

Lareschi, M., Mauri, R. 1998. Dermanyssoidea, In: Morrone, J.J., Coscarón, S. (Eds.) Biodiversidad de artrópodos 
argentinos, Una perspectiva biotaxonómica: 581-590. Ediciones SUR, La Plata, Argentina.

LEWIS, R.E. 1976. A review of the South American flea subgenus Ectinorus Jordan 1942, with descriptions of two new species and a key (Siphonaptera: Rhopalopsyllidae). Journal of Parasitology 62(6):1003-1009.

Moreno, L., Castro, D., Torres-Mura, J.C., GonzÁlez-Acuña, D. 2005. Phthiraptera (Amblycera and Anoplura) parasites of the Family Octodontidae, Ctenomyidae and Abrocomidae (Mammalia: Rodentia) from Chile. Rudolstädter Naturhistorische Schriften. Supplement 13:115-118.

Muñoz-Pedreros, A., Gil, C.C. 2009. Orden Rodentia. In: MuñozPedrero, A., Yáñez, J. (Eds.) Mamíferos de Chile: 93-157. CEA Ediciones, Santiago, Chile.

PlazA, P. 2013. Ectoparásitos de la yaca común (Thylamys elegans) y la yaca del norte (Thylamys pallidior) en el norte de Chile. Seminario de Titulo, Medicina Veterinaria. Universidad de Concepción, Concepción, Chile.

Price, R.D., Timm, R. 2000. Review of the chewing louse genus Abrocomophaga (Phthiraptera: Amblycera), with description of two new species. Proceedings of the Biological Society of Washington 113(1):210-217.

R Development Core Team. 2009. R: A language and environment to statistical computing. $\mathrm{R}$ foundation for Statistical Computing, Vienna computing. R Foundation for Statistical Computing, Vienna. URL: http://www.R-project.org.

SÁnchez, J., Amor, V., BAzÁn-León, E.A., VÁsquez, R., LAREschi, M. 2012. Redescription of Neotyphloceras chilensis Jordan, new status (Siphonaptera: Ctenophthalmidae: Neotyphloceratini). Zootaxa 3259:51-57.

Silva de la Fuente, M.C. 2014. Taxonomía y factores ecológicos que afectan a ácaros Mesostigmata asociados a roedores del norte de Chile. Tesis de Magister. Universidad de Concepción, Concepción, Chile.

TILl, W.M. 1963. Ethiopian mites of the genus Androlaelaps Berlese s. lat. (Acari: Mesostigmata). Bulletin of the British Museum (Natural History), Zoology 10(1):1-104.

Tipton, V.J., Altman, R.M., KeEnan, C.M. 1966. Mites of the subfamily Laelaptinae in Panamá (Acarina: Laelaptidae). In: Wenzel, R.L., Tipton, V.J. (Eds.) Ectoparasites of Panamá: 23-82. Field Museum of Natural History. Chicago, Illinois, USA.

VALIM, M. 2010. Sistemática e análise cladística das espécies do gênero Gyropus Nitzsch (Phthiraptera, Amblycera, Gyropidae). Tesis de Doctorado, Universidad Federal de Minas Gerais, Brazil.

Recibido: 12.04 .2018

Aceptado: 28.05 .2018 